\title{
Impact Study of Environment on Health during Covid-19 Lock down: A Review
}

\author{
Sridevi Tallapragada ${ }^{1}$, Rajesh Lather ${ }^{1 *}$, Vandana and Gurnam Singh ${ }^{2}$ \\ ${ }^{1}$ KrishiVigyan Kendra, Panchkula (Haryana), India \\ ${ }^{2}$ ChaudharyCharan Singh Haryana Agricultural University, Hisar, India \\ *Corresponding author
}

\section{A B S T R A C T}

\section{Keywords}

Lock down, COVID-19, PM2.5, PM10, Pollutants, Air Quality Index

Article Info

Accepted:

15 January 2021

Available Online:

10 February 2021
Investigations have been made on the issue of COVID-19 pandemic spread in India in the current challenging scenario. Trend knowledge has been observed with the help of recovery rate and case load rate obtained for the data available. The various strategies implemented as lockdown; quarantine of population has played a significant role in reducing the risk of spread of epidemic. This study predicts that when the case load rate gets lesser than recovery rate, there after COVID-19 patients would start to decline. On the other hand, many cities were ranked as the most polluted city in the world by WHO in May 2014. The usual air quality of India's national capital according to the air quality index used to be 200 and is 25 percent above unsafe level as deemed by World Health Organization. In Mumbai, the financial capital, air quality levels in March 2019 averaged 153 on the Air Quality Index and of national capital New Delhi averaged 161 which ranks as unhealthy to breathe. The government data shows the average concentration of PM 2.5 plunged by 71 percent in the space of a week falling from 91 $\mu \mathrm{g} / \mathrm{m}^{3}$ to $26 \mu \mathrm{g} / \mathrm{m}^{3}$. Reports from NASA shown that hole in ozone layer has filled up. The carbon monoxide level decreased from $600-1000 \mu \mathrm{g} / \mathrm{m}^{3}$ to $500-800 \mu \mathrm{g} / \mathrm{m}^{3}$. This is big impact of lockdown. Critically endangered, South Asian River Dolphins also known as Ganges Dolphins have been spotted back in the Ganga River after 30 years. Due to the reduced pollution in water, the South Asian River Dolphins have been spotted at various Ganga Ghats of Kolkata. The noise pollution fell as lockdown rings in sound of silence. Isolation, physical distancing, the closure of schools and workplaces proved challenges that affect people, and increased stress, anxiety, fear and loneliness at this time. The International Plant Protection Convention (IPPC) said that while the world battles COVID-19, plant pests and diseases continue to pose a threat to food production. Quarantine processes for samples of plant materials brought into the country for research purposes have been impacted due to the novel coronavirus disease (COVID-19)-associated lockdown. According to the World Organization for Animal Health (OIE), in the short term, some of the veterinary activities regarded as essential by the OIE, such as preventative measures against diseases with a significant public health or economic impact, are already either working at lower intensity or have been suppressed during the lockdown.

\section{Introduction}

Coronaviruses (CoVs) are a group of viruses which affects human beings through zoonotic transmission. This is the third time in past two decades that novel virus has created pandemic condition, after Severe Acute Respiratory Syndrome (SARS) in 2003 and Middle East Respiratory syndrome corona virus 
(MERSCoV) in 2012 (Ramdan and Shaib, 2019; Zhong et al., 2003). Pertaining to the Corona virus (2019), it was on December 31, 2019 wherein first case was reported to WHO Country Office in Wuhan, China with symptoms of unexplained low respiratory infections. This was classified as "pneumonia of unknown etiology" as the cause of infection was not known. On January 12, 2020, WHO found that Corona virus was the reason of this infection in Wuhan and later on 11th February, WHO Director-General announced this novel CoV as 'COVID-19' which is an acronym of 'Corona virus disease 2019' (Becarrio, C. et al., 2020). Covid-19 contains a single-stranded RNA as nuclei material and is $65 \mathrm{~nm}-125 \mathrm{~nm}$ in diameter (Shereen et al., 2020).

The major causes of concern for Covid-19 includes its global scale transmission, repeated emergence, significant number of deaths, infection and mortality to care providers and multiplicative effect in vulnerable or susceptible groups. Covid-19 was declared pandemic disease by Director General-WHO on $11^{\text {th }}$ March. He also briefed regarding the 13-fold increase in positive cases in China and 114 countries suffering form 1,18,000 positive cases and 4291 deaths till date (World Health Organization, 2020). In India the first confirmed positive case was reported on $30^{\text {th }}$ January in a student from Thrissur district of Kerala who had returned home for a vacation from Wuhan University in China (India Today, 2020a) followed by two other cases on February 2 and 3 again in Kerala having the same history. As on 14th April, Ministry of Health \& Family Welfare (MOHFW) reported 10,815 positive cases and 358 deaths covering 32 states in India. Presently in comparison to the top six affected countries viz USA, Italy, Spain, China, Germany and Iran, we in India have lesser capacity to serve patients. With a population of 1.2 billion, India has only 118 Government approved testing laboratories, 1.1363 beds per thousand patients (China has 4.2) and more than one million tests done. On the contrary, India has the highest recovery rate of $41.39 \%$ as compared to Italy $(16.91 \%)$ and USA $(3.17 \%)$ which is the direct effect of lockdown. Although, the researchers round the globe are rigorously working to find the cure of the infection caused by this deadly virus but unfortunately, till date no definite cure or vaccine has got developed. The only way to control the spread of this virus at this moment is suggested to be "social distancing", which is being practiced by many countries at this crisis time and has led to reduction GHG emissions in air (ZambranoMonserrate et al., 2020) at global level. During past two decades, India has witnessed an expeditious industrial growth which has certainly improved the standard of living of its people and it is also evident from the rising vehicular fleet on roads. But we have paid a heavy cost for this development in terms of poisoning the air we breathe. As per press release of World Health Organization (2nd May 2018), around 7 million people die every year from exposure to fine particles in polluted air (World Health Organization, 2018). State of India's Environment (SoE) report, 2019 has declared that $12.5 \%$ of all deaths in India are due to Air Pollution (India Today, 2020b).

The impact of air pollution on Indian population and their health was extensively studied in past by several researchers. The Urban air quality management strategies were planned which concentrated on emission inventory, control strategies, monitoring network and participation of public (Gulia et $a l ., 2015)$.The Earth, the air, the land and the water are not an inheritance from our forefathers but on loan from our children. So, we have to handover to them, at least, as it was handed over to us. Fig. 1 shows the spread of COVID-19 from January 30, 2020 to April 14, 2020. It is evident from the figure that spread of corona virus became rapid after 
15 March and started taking a horrible shape in entire country. The environment with physical, biological and physiological components is all of the external and internal factors affecting an organism. These factors may be other living organisms (biotic factors) or nonliving variables (abiotic factors), such as temperature, rainfall, day length, wind, and ocean currents.

The interactions of organisms with biotic and abiotic factors form an ecosystem. On the other hand, health is a state of complete physical, mental and social well-being and not merely the absence of disease. It is a condition under which the individual is able to mobilize all his resources, intellect, emotional and physical for optimum living.This paper provides evidence-based insight into improvement of air quality and environment during pre and post lockdown of this pandemic situation. An attempt has been made to visualize the improvement in the air quality using tools like satellite images of Indian atmosphere, results of onsite real-time monitoring at specific locations (Ghaziabadhighest polluting city of India) and Air quality index (AQI) calculated by central pollution control board of India.

\section{Impact}

The world will have to face many long term and short terms effects of Covid-19. The patients who had developed Acute Respiratory Distress Syndrome (ARDS) being Corona positive, will be at greater risk of long-term health issues related to major organs like heart, lungs etc. People who have recovered from this disease may have posttraumatic stress disorder (PTSD), depression and anxiety. India, in its fight against the coronavirus, has opted to enforce the harshest but among the most effective forms of nationwide lockdown on $24^{\text {th }}$ march, 2020. In one country after the other, lockdowns have emerged as the key response against the coronavirus pandemic.

The Covid-19 lockdown is healing the planet in a way never seen before in living history. Data from the Central Pollution Control Board of India's Environment Ministry also showed a 71 percent decrease in nitrogen dioxide levels. Mumbai, Chennai, Kolkata and Bangalore have also recorded a drop in these air pollutants, according to the pollution control board. In Mumbai, the financial capital, air quality levels in March 2019 averaged 153 on the Air Quality Index and of national capital New Delhi averaged 161 which ranks as unhealthy to breathe, according to Reuters. The pollutants which are used as main criteria to measure air quality index showed.

Table.1

\begin{tabular}{|c|c|c|c|c|}
\hline $\begin{array}{l}\text { Sr } \\
\text { No }\end{array}$ & Pollutant & Source & Average during 2017-19 & $\begin{array}{c}\text { Figure speaks after } \\
\text { lockdown }\end{array}$ \\
\hline 1 & PM 2.5 & Combustion & $100-140$ microgram/ m ${ }^{3}$ & 35 microgram/ $\mathrm{m}^{3}$ \\
\hline 2 & PM 10 & Road \& construction dust & 200 microgram $/ \mathrm{m}^{3}$ & $35 \mathrm{microgram} / \mathrm{m}^{3}$ \\
\hline 3 & $\begin{array}{l}\text { Sulphur } \\
\text { Dioxide }\end{array}$ & $\begin{array}{l}\text { Fossil fuel combustion(Diesel, } \\
\text { coal, etc) }\end{array}$ & - & Reduced significantly \\
\hline 4 & $\begin{array}{l}\text { Nitrogen } \\
\text { dioxide }\end{array}$ & Factory output \& Vehicle Exhaust & - & $\begin{array}{l}\text { Reduced drastically } \\
\text { up to } 80 \%\end{array}$ \\
\hline 5 & $\begin{array}{l}\text { Carbon } \\
\text { Monoxide }\end{array}$ & $\begin{array}{l}\text { Vehicle Exhaust } \\
\text { \& Combustion of carbon }\end{array}$ & 600 to $1000 \mu \mathrm{g} / \mathrm{m} 3$ & 500 to $800 \mu \mathrm{g} / \mathrm{m} 3$ \\
\hline 6 & Ozone & $\begin{array}{c}\text { Reaction of } \mathrm{NO} \text { and } \mathrm{VOC}(\text { Volatile } \\
\text { Organic Compond) }\end{array}$ & $15-40 \mu \mathrm{g} / \mathrm{m} 3$ & $25-70 \mu \mathrm{g} / \mathrm{m} 3$ \\
\hline
\end{tabular}




\section{Improvement in air quality}

The lockdown appears to show pronounced improvement in air quality over these large densely populated metropolitan footprints of India where US embassies are located, but the lives of hundreds of millions of Indian people have been disrupted due to the lockdown in response to the COVID-19 pandemic. Our results show a pronounced decline in air pollutants during lockdown especially in Delhi and Kolkata; these two cities are known to be highly polluted cities in India and in the world. The results will attract the attention of the Indian Government to ponder on how to strictly minimize vehicular and industrial pollution to improve air quality which will help to sustain better public health in India. New Delhi was ranked as the most polluted city in the world by WHO in May 2014 The usual air quality of India's national capital according to the air quality index used to be 200 and is 25 percent above unsafe level as deemed by World Health Organization.

The government data shows the average concentration of PM 2.5 plunged by 71 percent in the space of a week falling from 91 microgram $/ \mathrm{m}^{3}$ to 26 microgram $/ \mathrm{m}^{3}$. Reports from NASA shown that hole in ozone layer has filled up. Before the lockdown, the daytime average of Ozone was in the range of $15-40 \mu \mathrm{g} / \mathrm{m} 3$ and after the lockdown, it is considerably higher, at $25-70 \mu \mathrm{g} / \mathrm{m} 3$. This is because of chemistry. NOx consists of NO and NO2. NO eats ozone and NO2 makes ozone. Transport is responsible for more than $50 \%$ of the NOx emissions in the city. So, with a limited amount of NO present, ozone accumulates. This is big impact of lockdown. Aerosols adversely affect human health by degrading the air quality which results to premature mortality through lung cancers and cardiopulmonary diseases (Partanen et al., 2018).
Suspended road dust and construction dust are major PM10 contributors. With limited traffic, road dust is under control, and with a complete ban on construction activities, the overall PM10 level has dropped to its lowest day-wise average, at $35 \mu \mathrm{g} / \mathrm{m}^{3}$. However, dust storms from the west briefly increased the levels since April 10, for 2017-2019, the annual average PM10 level in Delhi was 200 $\mu \mathrm{g} / \mathrm{m}^{3}$.The health risks associated with particulate matter of less than 10 and 2.5 microns in diameter $\left(\mathrm{PM}_{10}\right.$ and $\left.\mathrm{PM}_{2.5}\right)$ are especially well documented. PM is capable of penetrating deep into lung passageways and entering the bloodstream causing cardiovascular, cerebrovascular and respiratory impacts. In 2013, it was classified as a cause of lung cancer by WHO's International Agency for Research on Cancer (IARC). It is also the most widely used indicator to assess the health effects from exposure to ambient air pollution. In children and adults, both short- and long-term exposure to ambient air pollution can lead to reduced lung function, respiratory infections and aggravated asthma. Maternal exposure to ambient air pollution is associated with adverse birth outcomes, such as low birth weight, pre-term birth and small gestational age births. Emerging evidence also suggests ambient air pollution may affect diabetes and neurological development in children. Considering the precise death and disability toll from many of the conditions mentioned are not currently quantified in current estimates, with growing evidence, the burden of disease from ambient air pollution is expected to greatly increase.

\section{Data analysis of north India during lockdown from Feb-June}

Carbon monoxide (CO) has the longest tropospheric lifetime - approximately two months - of the criteria pollutants, and its levels are incapable of changing quickly. The 
daytime averages during February-March ranged from 600 to $1000 \mu \mathrm{g} / \mathrm{m}^{3}$ and during the lockdown period, from 500 to $800 \mu \mathrm{g} / \mathrm{m}^{3}$.

\section{Data analysis of north India during lockdown from Feb-June}

As the graph indicates, the drop in nitrogen dioxide (NO2) is dramatic enough as well as more discernible compared to the other pollutants. This is because its main source is vehicle exhaust. With nearly $90 \%$ of vehicles off the road, the change is evident at ground stations and visible even in satellites' columnar observations over China, Italy and the USA.

\section{Data analysis of north India during lockdown from Feb-June}

The impact of air pollution on Indian population and their health was extensively studied in past by several researchers. The Urban air quality management strategies were planned which concentrated on emission inventory, control strategies, monitoring network and participation of public (Gulia et al., 2015). A general comparison between the major air pollutants was also studied and the impact of industrialization transportation and other anthropogenic activities were analyzed (Singh et al., 2007). In this paper information from several government and nongovernment agencies have been collected and analyzed to understand the change in quality of various environmental factors such as air and water quality due to lockdown caused by Covid-19.

\section{Improvement in water quality}

Number of rivers of India including Ganga, Cauvery, Sutlej and Yamuna etc get purified. The primary cause is lack of industrial effluents entering the rivers due to lockdown situation under this pandemic situation. The
DO levels of river Ganga as per reports has gone above $8 \mathrm{ppm}$ and BOD levels down below $3 \mathrm{ppm}$ at Kanpur and Varanasi (SANDRP, 2020) which ranged around 6.5 ppm and 4 ppm in 2019 respectively (Pathak and Mishra, 2020). It is reported that in routine days the total effluent dumped in Ganga is around 6500-6700 MLD and out of which 700 MLD (approximately 10\%) come from industries. $30 \%$ of total BOD is due to industries situated along the holy river which is 130-150 tons per day. The organic load can be diluted in the river but the industrial pollution destroys the self-cleansing property of water. Researchers believe that the selfcleansing property of river Ganga has improved which has enhanced the water quality by $40-50 \%$ during this lockdown (Hindustan Times, 2020a). Scientists have claimed that water quality has remarkably improved at Haridwar Ghats which is up to drinking standards (News18 Buzz, 2020). The Ghats are also closed for people taking holy bath in the water or dumping flowers and other waste in it has stopped. This has resulted in water looking visibly cleaner with aquatic life moving around. Figure below show the clean waters of Ganga at Haridwar. River Yamuna also in most parts of Delhi is appearing clearer, blue and pristine after years.

The toxic foam caused due to mix of detergents, chemicals from industries and sewage has vanished clearly in southeast Delhi's KalindiKunj. As per Karnataka State Pollution Control Board, the quality of water in Cauvery and tributaries like Kabini, Hemavati, Shimsha and Lakshamanathirtha is also back to what it used to be before decades (The Hindu, 2020). The pollution discharge has drastically fallen sharply in Buddha nullah which carries effluents from 2423 industrial units into Satluj River in Punjab during this lockdown (Hindustan Times, 2020b). 
There is a great association between pollution and health problem. Disease causing microorganisms are known as pathogens and these pathogens are spreading disease directly among humans. Some pathogens are worldwide, some are found in well-defined area. Many water borne diseases are spreading man to man. Health risk associated with polluted water includes different diseases such as respiratory disease, cancer, diarrhea disease, neurological disorder and cardiovascular disease. Nitrogenous chemicals are responsible for cancer and blue baby syndrome. Mortality rate due to cancer is higher in rural areas than urban areas because urban inhabitants use treated water for drinking while rural people don't have facility of treated water and use unprocessed water. Contaminated water has large negative effects in those women who are exposed to chemicals during pregnancy; it leads to the increased rate of low birth weight as a result fetal health is affected. An iron clog in to fish gills and it is lethal to fishes, when these fishes are eaten by human leads to the major health issue. Metal contaminated water leads to hair loss, liver cirrhosis, renal failure and neural disorder. Critically endangered, South Asian River Dolphins also known as Ganges Dolphins have been spotted back in the Ganga River after 30 years. Due to the reduced pollution in water, the South Asian River Dolphins have been spotted at various Ganga Ghats of Kolkata. Undoubtedly water quality improved.

\section{Reduced noise pollution}

Noise pollution impacts millions of people on daily basis. The most common health problem it causes is Noise Induced Hearing Loss (NIHL). Exposure to loud noise can also cause high blood pressure, heart disease, sleep disturbances, and stress. These health problems can affect all age groups, especially children. Many children who live near noisy airports or streets have been found to suffer from stress and other problems, such as impairments in memory, attention level, and reading skill. Noise pollution also impacts the health and well-being of wildlife. Studies have shown that loud noises cause caterpillars' hearts to beat faster and bluebirds to have fewer chicks. Animals use sound for a variety of reasons, including to navigate, find food, attract mates, and avoid predators. Noise pollution makes it difficult for them to accomplish these tasks, which affects their ability to survive. Increasing noise is not only affecting animals on land, it is also a growing problem for those that live in the ocean. Ships, oil drills, sonar devices, and seismic tests have made the once tranquil marine environment loud and chaotic. Whales and dolphins are particularly impacted by noise pollution. These marine mammals rely on echolocation to communicate, navigate, feed, and find mates, and excess noise interferes with their ability to effectively echolocate. (National Geographical Society).The noise pollution falls as lockdown rings in sound of silence. Honking of vehicles is one of the biggest noise polluters recorded daily sound with decibel level going up to 100 and higher at Govidpuri metro station area reduced to 50 during lock down period. Most of the residential area in Delhi now clocking 30-40 dB (A), down from the usual of $55 \mathrm{~dB}(\mathrm{~A})$.

\section{Increased mental health issues}

Isolation, physical distancing, the closure of schools and workplaces proved challenges that affect people, and it is natural to feel stress, anxiety, fear and loneliness at the time. Not surprisingly, COVID-19 Lockdown causing increased mental health issues. Investigators at the University of Sydney showed that adults in locations with more COVID-19 cases had higher levels of distress, as well as lower levels of physical 
and mental health and life satisfaction. It's also observed that people who exercise that much routinely do so in gyms or in group situations that are part of their typical social activities, which changed dramatically during lockdown. The 'stigma' attached to COVID19 and the concerned calls by friends and family also adds to this stress. Studies show that it would be common to see an increase in stress, depression and anxiety, both in the general population and among frontline workers aiding efforts to combat the virus. This lockdown recognizes the strength of social, economical, political and environmental influences on health. The ministry of health and family welfare said that in order to combat the mental health impact of the lockdown on individuals, the National Institute of Mental Health and NeuroSciences (NIMHANS), Bengaluru based premier medical institution has launched a toll-free number - 08046110007 - for consultation. The sparse literature on the mental health consequences of epidemics relates more to the sequelae of the disease itself (eg, mothers of children with congenital Zika syndrome) than to social distancing. However, largescale disasters, whether traumatic (eg, the World Trade Center attacks or mass shootings), natural (eg, hurricanes), or environmental (eg, Deepwater Horizon oil spill), are almost always accompanied by the increase in depression, posttraumatic stress disorder (PTSD), substance use disorder, a broad range of other mental and behavioral disorders, domestic violence, and child abuse. In the context of the COVID-19 pandemic, it appears likely that there will be substantial increase in anxiety, depression, substance use, loneliness, domestic violence; and with schools closed, there is a very real possibility of an epidemic of child abuse. This difficult moment in time nonetheless offers the opportunity to advance our understanding of how to provide prevention focused, population-level, and indeed national-level psychological first aid and mental health care, and to emerge from this pandemic with new ways of doing so.

Investigations have been made on the issue of COVID-19 pandemic spread in India in the current challenging scenario. Trend knowledge has been observed with the help of recovery rate and case load rate obtained for the data available. The various strategies implemented as lockdown; quarantine of population have played a significant role in reducing the risk of spread of epidemic. This study predicts that when the case load rate gets lesser than recovery rate, there after COVID-19 patients would start to decline. India reported over 5.2 million cases of the coronavirus (COVID-19) as of September 18, 2020, with more than 4.1 million recoveries and about 84 thousand fatalities. The country has been reporting new cases of the virus every day since March 2, 2020. While the number of new cases has been growing, some patients who tested positive under quarantine have made full recoveries.

\section{How to enhance mental health when working from home}

Set up a dedicated workspace which should be as free from distractions as possible.

Develop a schedule which includes phases of focused work as well as breaks.

If possible, divide and share times dedicated to child and pet care.

If possible, work in a different room than the one you spend your leisure time in. Particularly avoid working in your bedroom as it may remind you of work related issues, preventing detachment when you go to sleep. (If you don't have the option of a different room, then try to tidy away everything that may remind you of work.)

Refrain from all forms of work related communication during non-work time. 
Engage in absorbing activities, which capture your full attention after work. Good examples include exercise, cooking, mindfulness meditation, or focused playing with your children or pets.

\section{Impact on plant health}

The International Plant Protection Convention (IPPC) said that while the world battles COVID-19, plant pests and diseases continue to pose a threat to food production. Quarantine processes for samples of plant materials brought into the country for research purposes have been impacted due to the novel coronavirus disease (COVID-19)associated lockdown, according to the National Bureau of Plant Genetic Resources (NBPGR) of the Indian Council of Agricultural Research. In an interview with Mongabay-India, NBPGR scientists discuss the challenges in plant quarantine for research samples under the lockdown, the gaps in plant biosecurity in India and implications for a post-COVID world. The COVID-19 pandemic may have affected a range of measures needed to ensure plant health. They include quarantine measures, implementation of plant health regulations, especially those related to plant passporting requirements. In addition, emergency authorization processes, needed to contain quarantine pests, may have been affected, yet the urgent threat of such pests requires a prompt intervention. Quarantine staff or inspectors of consignments at the borders may be exposed to sanitary risks due to the COVID-19 pandemic. For example, it is yet unclear whether the existing biosecurity systems remained fully operational during the pandemic for an effective surveillance and management of potential biological threats to plant health or whether these systems were relaxed or restricted to some extent. In particular, it is critical to recognize that the future of global food security and safety is linked across borders. A weak biosecurity in one country not only threatens neighbouring countries and/or continents but the entire planet. Reviewing regulations and their implementation to secure crop protection, harvests and food supply is thus critical to safeguard food systems. Application of science-based preventive actions, including quarantine measures to contain invasive pests threatening global food security and safety is critical to protect plant health.

\section{Impact on animal health}

According to the World Organization for Animal Health (OIE), in the short term, some of the veterinary activities regarded as essential by the OIE, such as preventative measures against diseases with a significant public health or economic impact, are already either working at lower intensity or have been suppressed during the lockdown. This, in addition to other short-term effects such as increased wildlife-livestock contacts, less population control, or longer on-farm stays of stock, will trigger effects on the distribution and incidence of transmissible animal diseases (O'Neill et al., 2020). If the economic crisis evolves into a deep and long depression, the overall capacity of regional, national and supra-national veterinary services might be compromised. Thus, the long-term effects of COVID-19 on animal health will largely depend on the impact of the crisis on farmer livelihoods and on the capacities of the animal health services (Woods, 2011; Schwabenbauer, 2012).

The following actions might contribute to buffering these adverse effects of COVID-19 on animal health. Short term recommendations are to avoid an interruption to ongoing vaccination or test and cull schemes, or at least to limit such interruptions as little as possible; and to pay special attention to changes in pathogen distribution 
during and after the confinement period. Suggested long-term actions include adapting animal health management strategies to the available resources. Awareness of the socioeconomic context of disease control is required for greater disease control success (Schwabenbauer, 2012), and the potential for a future of concatenated shocks requires adaptations in both science and governance (Biggs et al., 2011). Thus, while investment in animal health should be maintained as a priority despite the economic crisis, greater use of co-funding from the private farming sector will be needed, leading in return to a transfer of management and decision-making to the relevant sector. For instance, TB management is run by a public-private partnership in New Zealand (https://ospri.co.nz/; last access 09/04/2020) and in the UK, the Godfrey report (DEFRA, 2020) proposes that TB management is removed from government to make it easier for the new body to work collaboratively with industry and other stakeholders.

Fig.1

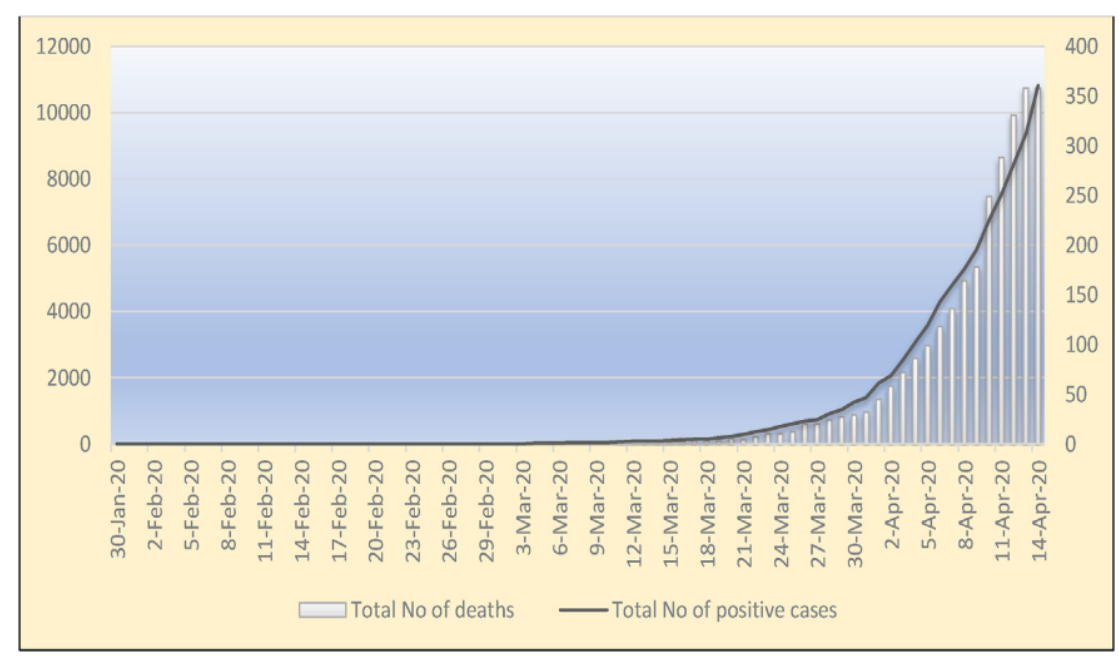

Fig.2

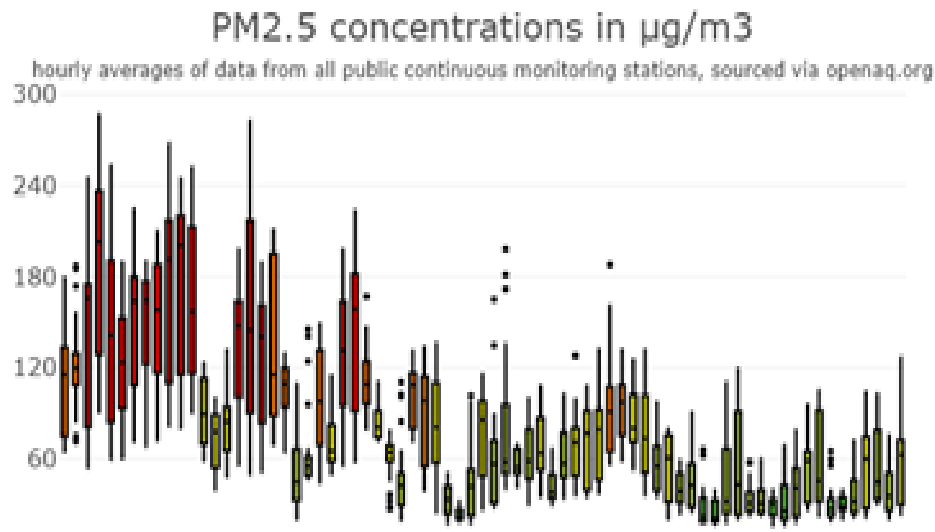

Data analysis of north India during lockdown from Feb-June 
Fig.3

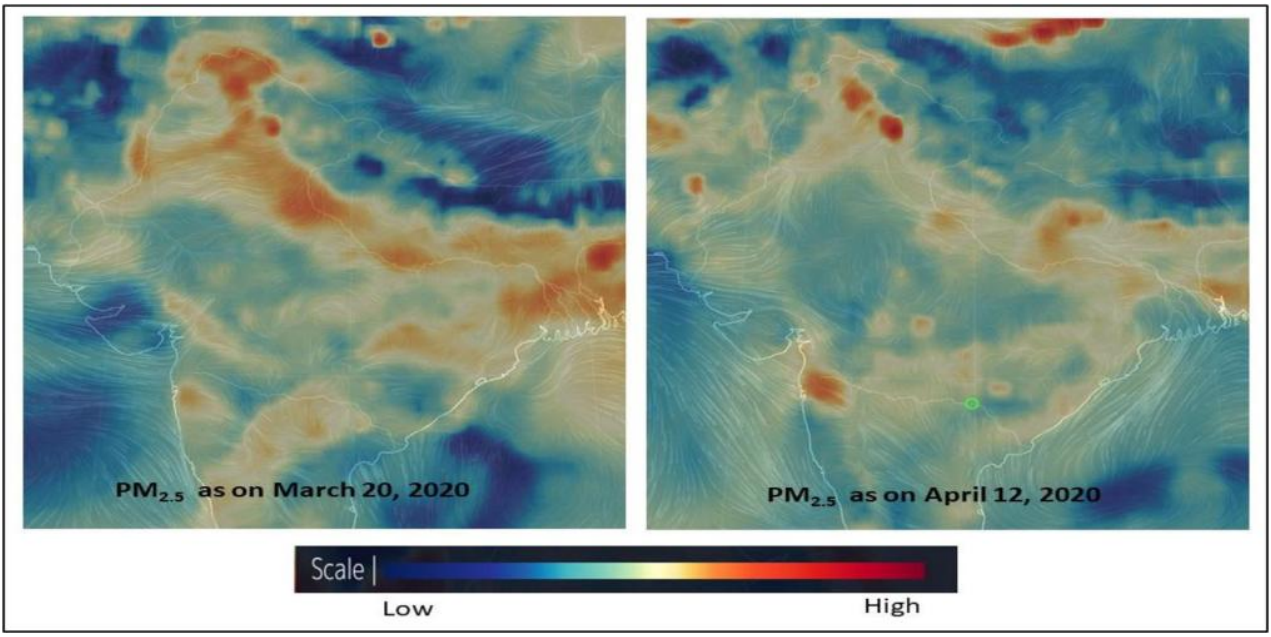

Fig.4

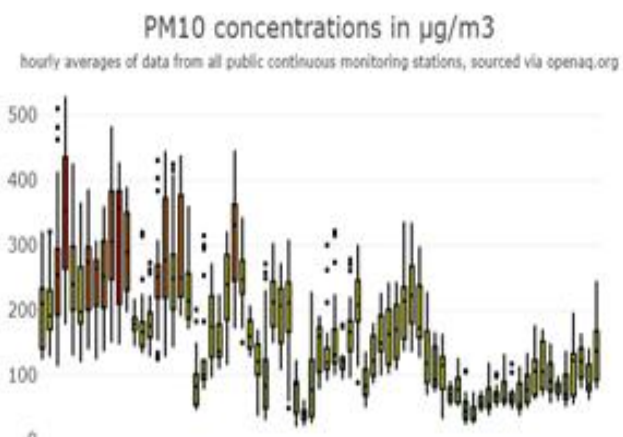

Data analysis of north India during lockdown from Feb-June

Fig.5

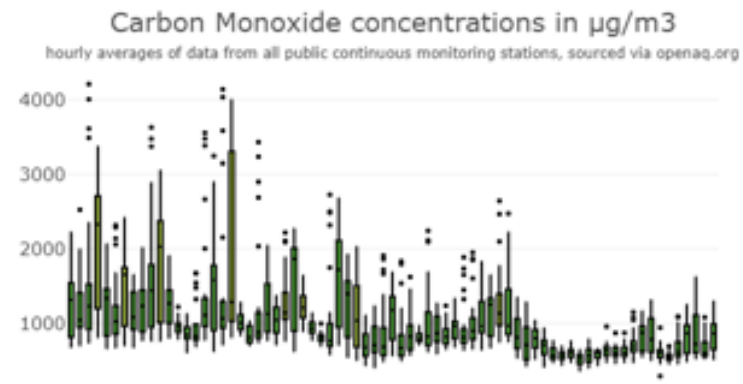


Fig.6

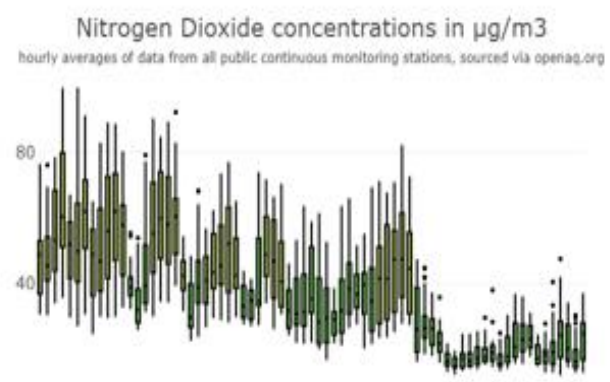

Fig.7

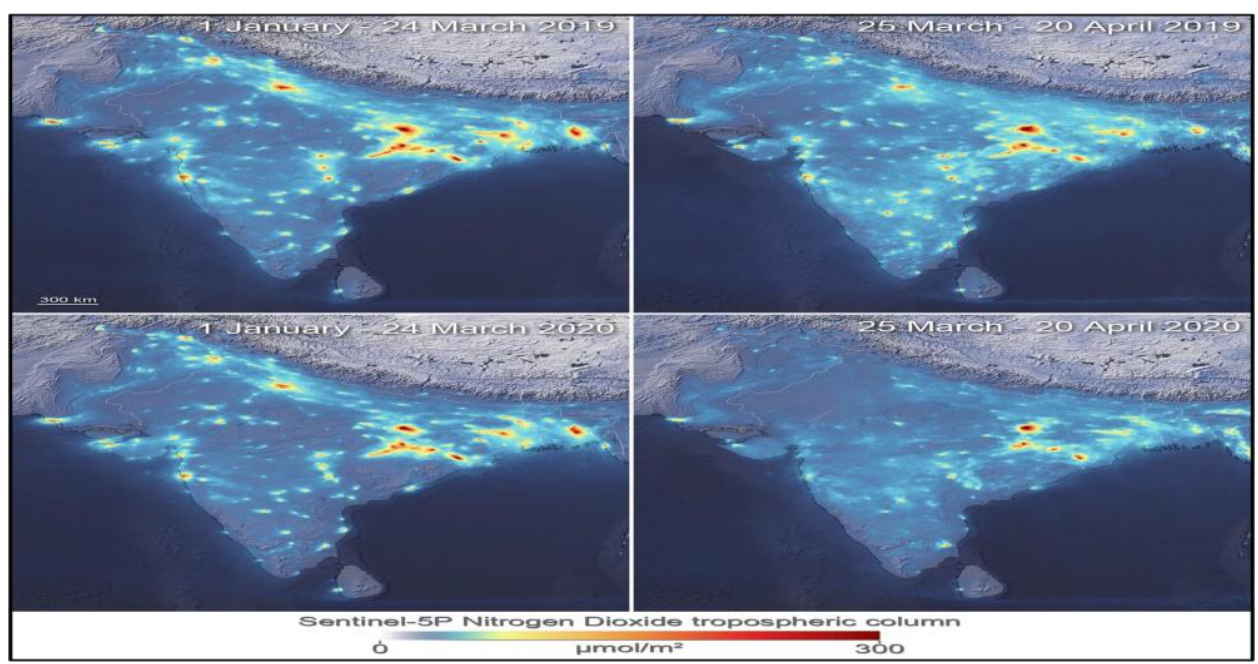

Fig.8

Sulphur Dioxide concentrations in $\mu \mathrm{g} / \mathrm{m} 3$

houdy averages of data frem al pubic contecous moeitoring stations, sources via openagere

00

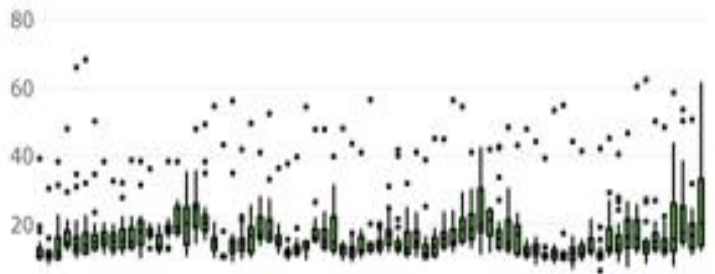


Fig.9

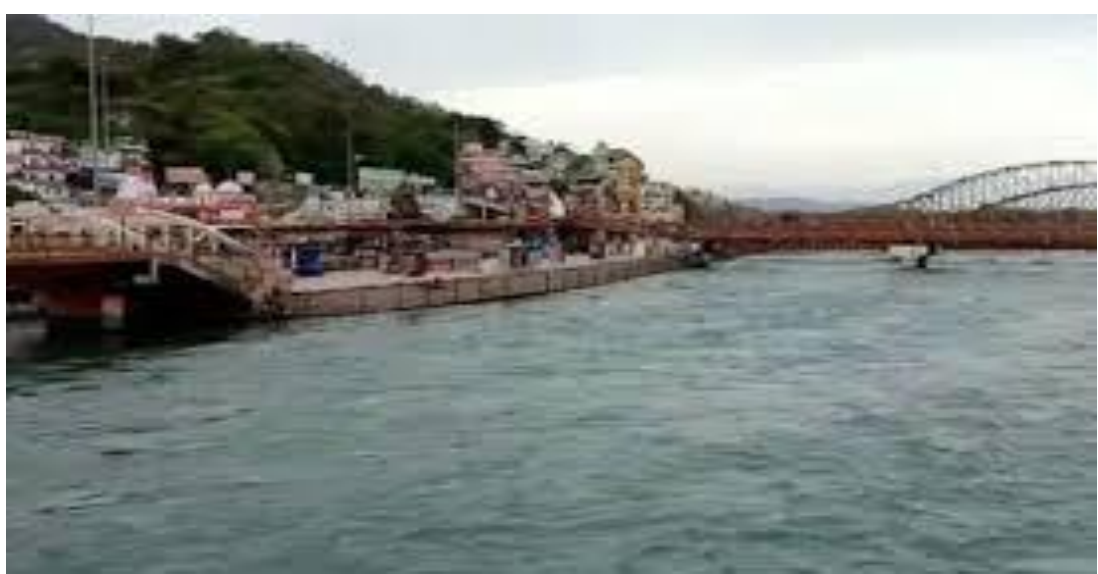

Fig.10

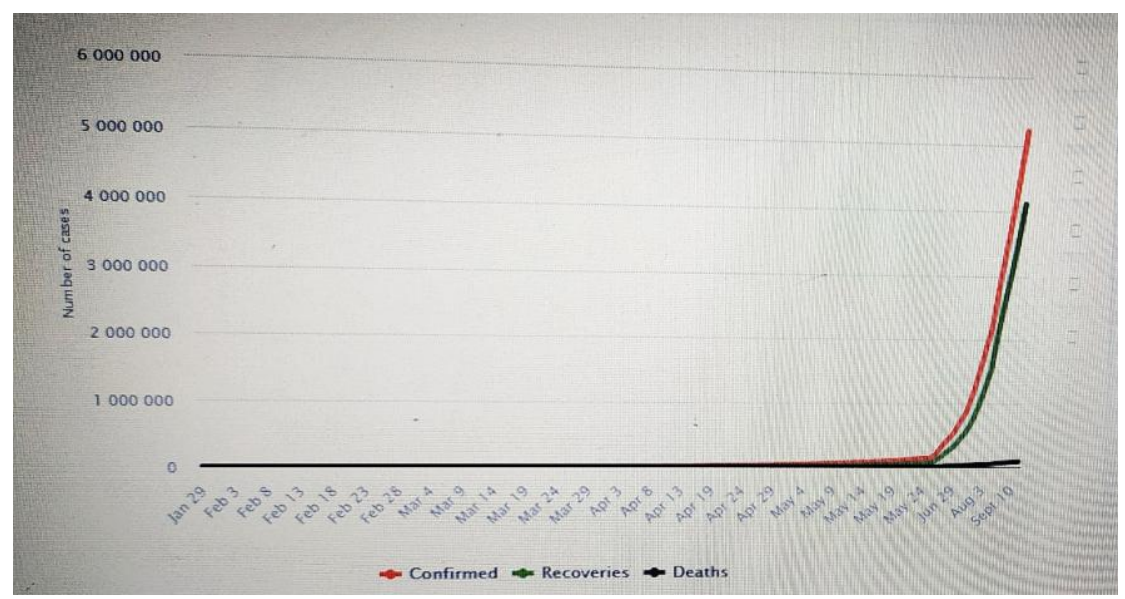

\section{Impact on marine life}

According to Andrew Hudson, the head of Water and Ocean Governance Programme, under United Nation Development Programme the dramatic global economic slowdown caused by COVID-19 is having pervasive effects not only on jobs, economies and governments but also on marine ecosystems. In the near term, the impacts of COVID-19 on the health of the ocean have largely been positive due to the reduction in various sectoral pressures that lead to pollution, overfishing, habitat loss/conversion, invasive species introductions and the impacts of climate change on the ocean. While the ocean may enjoy some near-term benefits, the livelihoods and food security of tens or even hundreds of millions of people may be seriously affected.

There is already evidence that significant slowdowns are occurring in fisheries, shipping, coastal tourism, coastal development, and oil and gas extraction. In a recent informal poll conducted by the Economist during one of its World Ocean Initiative webinars, participants ranked the following ocean sectors as impacted most by COVID-19: tourism 70.7 percent, fisheries 10.4 percent, offshore oil and gas 7.2 percent, shipping 6.2 percent, offshore renewables 2.9 percent and aquaculture 2.6 percent. 
A recent survey by the UNDP Global Environment Facility Global Sustainable Supply Chains for Marine Commodities project showed significant reductions in demand for shrimp, octopus, crab, snapper, grouper, squid and mahi-mahi. This is due to lower demand from export markets, the challenge of practicing sanitary measures on fishing boats, difficulties accessing supplies and labour shortages. In the United States, two-thirds of commercial fish go to restaurants, many of which are now closed, so this demand has plummeted. In Ecuador, decreased demand for mahimahi, mainly due to the complete collapse of tourism, led to a significant reduction in prices and has made fishing unprofitable. In Florida, demand for lobster has declined due to elimination of markets in China.

The blue economy-including both those who work at sea and those whose livelihoods depend on it - presents a unique challenge for efforts to address the Covid-19 pandemic. Ports depend on the movement of goods and people, something antithetical to pandemic control. Many of the world's 4.5 million fishing vessels remain at sea for weeks or months at a time, leaving them intensely vulnerable to shipboard Covid-19 outbreaks that may arise from stops at harbors around the world. Fish is the world's most widely traded food commodity, but market disruptions, as a result of the pandemic, have already begun to change that. Consumers have dramatically increased demand for frozen and processed seafood while turning away from fresh caught products.

\section{Impact on wild life}

The world is fighting against an invisible opponent that has forced us all to push the 'PAUSE' button on our lives. This global pandemic has set off a ripple effect across nations and life as we know it has descended into rather dark times. This crisis has also had a deep impact on wildlife. While the world has come to a complete and utter standstill, nature seems to be reclaiming her territorywild animals near urban cityscapes are taking this opportunity to step beyond the comforts of their forested homes; a massive Nilgai (Blue-bull) wandering outside a Mall in Noida, India, coyotes basking in the parks of San Francisco, cougars roaming the streets of Santiago, Chile, penguins waddling across Cape Town and even sea lions in Mar Del Plata harbour in Argentina! - the denizens of the world are witnessing some rare wildlife sightings. Secondly the global wildlife trade has been thrown into the spotlight. The massive impact of the coronavirus outbreak is the decline in wildlife trade which comes as a much-needed silver lining in these dark times. And thirdly, the wildlife tourism too has felt the impact of this pandemic. The global tourism industry has been one of the worst hit during this crisis due to travel restrictions and many countries shutting off their borders. This has brought some much-deserved relief to the elephants in countries like Thailand and India which are popular for elephant joyrides for tourists.

\section{Impact on Indian agriculture}

Doubling of the farmer's income program initiated and steered by central and state governments has certainly be adversely affected due to the ill effects of Covid-19 and subsequent lockdowns. The harvesting and threshing of rabi crops, making reach them to procurement marketing venues has badly affected. To minimize shattering of the grains in standing crops, particularly wheat crop due to the fear of accidental fire in the standing crop by electrical sparking, machinery fire or smoker's negligence, etc; the farmers were compelled to harvest and thresh the crops 2-5 days before actual ripening which affected the yields. Due to fear and uncertainty of the 
Covid-19 period and non-availability of casual jobs, as well as non-availability of permanent residence available for labor at their workplace, they moved to their native place. This again has doubled and trebled their miseries as well as of that of farmers. All this has certainly eroded the Indian Economy in general and farmers in particular. The situation was a fall out on vegetable \& fruit production system which is labor-intensive activity; and above all in the production of vegetables and fruits manual labor is a more practical proposition as compared to a mechanical one. Although all the crops have affected due to the impact of COVID -19, yet the most affected were sugarcane, vegetable $\&$ horticultural crops, cotton \& fresh-flower production. Sugarcane is a labor-intensive crop right from sowing till harvesting. Vegetables and horticultural crops require manual laborer from day one to the consumption point. Most of the vegetables and fruit crops are perishable and have a very short shelf-life; hence are required to be reached to the consumer in a time-bound manner. If manual labour is not timely available it brings a huge loss to the growers which directly impacts remuneration of the growers, and ultimately the consumer has to pay more price owing to demand-supply principle. Timely transportation of these commodities was another issue that spurted the prices of these commodities for the consumers of far-flung areas. Similarly, the quality of the commodities was badly affected due to such issues. The most affected agriactivity was the fresh- flower growing industry which has fallen flat owing to the non-availability of the labour force as well as its demand in the local and international markets.

\section{References}

Becarrio, C., 2020b. Retrieved from: https://earth.nullschool.net/\#current/part iculates/

surface/level/overlay $=$ pm10/orthographi $\mathrm{c}=70.81,22.26,636 / \mathrm{loc}=77.690,26.756$. Cascella, M., Rajnik, M., Cuomo, A., Dulebohn, S.C., Napoli, R.D., 2020. Features, Evaluation and Treatment Corona Virus (COVID-19), NCBI Bookshelf. StatPearls Publishing.

Biggs D., Biggs R., Dakos V., Scholes R.J., Schoon M. Are we entering an era of concatenated global crises? Ecol. Soc. $2011 ;$ 16(2) doi: 10.5751/ES04079-160227.

DEFRA Department for Environment, Food and Rural Affairs, UK. Policy Paper. 2020. Bovine TB strategy review: summary and conclusions.https://www.gov.uk/govern ment/publications/a-strategy-forachieving-bovine-tuberculosis-freestatus-for-england-2018-review/bovinetb-strategy-review-summary-andconclusions.

Gulia, S., Nagendra, S.M.S., Khare, M., Khanna, I., 2015. Urban air quality management - a review. Atmos. Pollut. Res. 6, 286-304. https://doi.org/10.5094/APR.2015.033. 2015.

Hindustan Times, 2020a. Anxiety-more-timeto-study-for-40k-students-stranded-in-

Kota. Retrieved from: www.hindustantimes.com/indianews/anxiety-more-time-to-studyfor40k-students-stranded-in-kota/storyLgCluBkrFEITG9qyX16IEI.html.

Hindustan Times, 2020b. Lockdown Effect Effluent Discharge in Ludhiana's Buddha Nullah Drops. Retrieved from: www.hindustantimes.com/cities/lockdo wn-effecteffluent-discharge-inludhiana-s-buddha-nullahrops/storyuUFPVk7yWWxBRW727ezt wK.html.

India Today, 2020a. Coronavirus in India: Tracking Country's First 50 COVID-19 
Cases;

what Numbers Tell. Retrieved from: www.indiatoday.in/india/story/coronavi rusin- India- tracking-country-s-first50-covid-19-cases-what-numbers-tell1654468- 2020-03-12.

India Today, 2020b. 1 lakh children under 5 years of age die from air pollution in India every year: Study. Retrieved from: www.indiatoday.in/educationtoday/lateststudies/story/air-pollutionindia-deaths-children-five-years-reportcentre-forscience-and-environment1543779-2019-06-06

News18 Buzz, 2020. Ganga River Water Has Now Become Fit for Drinking as Industries Remain Shut Due to Lockdown. Retrieved from: https://www.news18.com/news/ buzz/ganga-river-water-has-nowbecome-fit-for-drinking-as-industriesremain-shutdue-to-lockdown2575507.html.

O’Neill X., White A., Ruiz-Fons F., Gortázar C. Modelling the transmission and persistence of African swine fever in wild boar in contrasting European scenarios. Sci. Rep. 2020; 10:5895. doi: 10.1038/s41598-020-62736-y. [PMC free article] [PubMed] [CrossRef] [Google Scholar].

Partanen, A.I., Landry, J.S., Matthews, H.D., 2018. Climate and health implications of future aerosol emission scenarios. Environ. Res. Lett. 13 (2), 024028.https://doi.org/ 10.1088/17489326/aaa511.

Pathak, S.S., Mishra, P., 2020. A review of the Ganga river water pollution along majorurban centres in the state of Uttar Pradesh, India. Int. Res. J. Eng. Technol. 7 (3), 1202- 1210.

Ramdan, H., Shaib, H., 2019. Middle East respiratory syndrome Corona virus (MERSCoV):a review. Germs. PubMed-NCBI 9 (1), 35-42. https://doi.org/10.18683/germs.2019.11 55. eCollection 2019 Mar.

SANDRP, 2020. Ganga-Yamuna-Cauvery Flow Cleaner in Lockdown: what Can We Learn?" DRP News Bulletin, South Asia Network on Dams, Rivers and People (SANDRP). Retrieved from: www.sandrp.in/2020/04/06/drp-nb-6april-2020- ganga-yamuna-cauveryflow-cleaner-in-lockdown-what-canwe-learn/\#more-34730.

Schwabenbauer K. The role of economics for animal health policymakers. Euro Choices. 2012;11(2):18-22. doi: 10.1111/j.1746-92X.2012.00229.x.

Shereen, M.A., Khan, S., Kazmi, A., Bashir, N., Siddique, R., 2020. COVID-19 infection: origin, transmission, and characteristics of human coronaviruses. J. Adv. Res. 24, 91-98.

Singh, A.K., Gupta, H.K., Gupta, K., Singh, P., Gupta, V.B., Sharma, R.C., 2007. A comparative study of air pollution in Indian cities. Bull. Environ. Contam. Toxicol. 78, 411416.https://doi.org/10.1007/s00128007-9220-9.

The Hindu, 2020. Cauvery, Tributaries Look Cleaner as Pandemic Keeps Pollution Away. Retrieved from: www.thehindu.com/news/national/karna taka/cauvery-tributariesin-old-mysururegion-look-cleaner-as-pandemic-keepspollution-away/ article31210429.ece.

Woods A. A historical synopsis of farm animal disease and public policy in twentieth century Britain. Philos. Trans. Biol. Sci. 2011;366(1573):1943-1954. doi: $10.1098 /$ rstb.2010.0388.

World Health Organization, 2018. 9 Out of 10 People Worldwide Breathe Polluted Air, but More Countries Are Taking Action. Retrieved from: www.who.int/news-room/ detail/02-052018-9-out-of-10-people-worldwidebreathe-polluted-air-but-morecountries- 
are-taking-action.

World Health Organization, 2020. WHODirector-general-s-opening-remarks-atthemedia-briefing-on-covid-19. Retrieved from: www.who.int/dg/speeches/detail/ whodirector-general-s-opening-remarks-atthe-media-briefing-on-covid-19.

Zambrano-Monserrate, M.A., Ruano, M.A., Sanchez-Alcalde, A., 2020. Indirect effects of COVID-19 on the environment. Sci. Total Environ. 728,
138813. https://doi.org/10. 1016/j.scitotenv.2020.138813. Zhong, N.S., Zheng, B.J., Li, Y.M., Poon, L.L.M., Xie, Z.H., Chan, K.H., Li, P.H., Tan, S.Y., Chang, Q., Xie, J.P., Liu, X.Q., Xu, J., Li, D.X., Yuen, K.Y., Peiris, J.S.M., Guan, Y., 2003. Epidemiology and cause of severe acute respiratory syndrome (SARS) in Guangdong, People's Republic of China. Lancet 362, 1353-1358.

\section{How to cite this article:}

Sridevi Tallapragada, Rajesh Lather, Vandana and Gurnam Singh. 2021. Impact Study of Environment on Health during Covid-19 Lock down: A Review Article. Int.J.Curr.Microbiol.App.Sci. 10(02): 1863-1878. doi: https://doi.org/10.20546/ijcmas.2021.1002.221 